\title{
MODEL DEVELOPMENT OF SUCCESSION PLANNING IN SUBSIDIARY COMPANIES ENGAGED IN THE INSURANCE INDUSTRY
}

\author{
*Primadi Candra Susanto ${ }^{1}$, Naik Henokh Parmenas ${ }^{2}$ \\ ${ }^{1}$ Institut Transportasi dan Logistik Trisakti, Jakarta, Indonesia \\ ${ }^{2}$ Institut Teknologi dan Bisnis Kalbis, Jakarta \\ *Coresponding author. \\ E-mail addresses: primstrisakti@gmail.com
}

\section{Article history: \\ Received: \\ 3 March 2021 \\ Accepted: \\ 15 April 2021}

ARTICLE INFO

Available online:

4 Mei 2021

\begin{abstract}
In this study using the Qualitative Phenomenology Method, the purpose of this study is to provide input regarding the proper retention plan formulation procedures and provide input regarding the procedures for identifying talent readiness to meet the needs of a critical position. Based on the analysis of the application of succession planning in insurance companies, it can be concluded that the following matters The implementation of succession planning at the subsidiary company has not been carried out optimally because it is still at the create development plans stage or the 4th stage of the seven stages of the succession planning process, the company is mature enough Identified talent and talent mapping for 15 manager candidates to obtain 2 candidates in the Ready Now category, 8 candidates in the Ready With Development category and five candidates in the Not Ready Yet category. For the candidates mentioned above, the Company has also compiled a talent development strategy (talent development strategy), which includes a number of development programs, including in-house training, coaching and mentoring, as well as special assignments. The development program is adjusted to the proficiency level of each candidate, based on the results of the assessment that has been carried out. right by the Company. The output of the development program carried out is a number of talent readiness to fill critical positions in the Company. Based on the analysis that has been done, the talent readiness of the subsidiary company ranges from 1-2 years. To maintain the talents the Company already has, the Company has also prepared a retention planning strategy. The retention strategy undertaken by the Company is more aimed at increasing bounding with employees and to retaining quality employees. Retention efforts carried out by the Company include clear and directed career development programs, leadership programs, building open and comfortable communication patterns. with employees, employee recognition, and various employee welfare programs. With the development of appropriate succession planning and supported by effective retention planning efforts, the Company will be able to supply competent human resources and have a supply of talent to fill critical position needs. in the future.
\end{abstract}

Keyword: Succession Planning, Talent Management 


\section{INTRODUCTION}

With the Value of company (Be the Best, Respect, Innovation, No Fraud \& Service Excellence), this company has succeeded in having dozens of companies that have become loyal customers spread across several different industrial sectors.

Table 1. Gross Premium, Net Profit and Total Equity 2016 to 2019

\begin{tabular}{lcccc}
\hline \multicolumn{1}{c}{ Year } & $\mathbf{2 0 1 6}$ & $\mathbf{2 0 1 7}$ & $\mathbf{2 0 1 8}$ & \multicolumn{1}{c}{$\mathbf{2 0 1 9}$} \\
\hline Net Income & 105.532 & 123.185 & 133.774 & 174.267 \\
\hline Total Equity & 565.558 & 632.869 & 736.830 & 841.104 \\
\hline Gross Premium & 1.027 .974 & 1.169 .063 & 1.332 .783 & 1.540 .726 \\
\hline
\end{tabular}

Note: Figures are read in millions of rupiah

By the end of 2020, the Company had succeeded in fulfilling 70\% (35 people) and still had to meet 30\% (15 people) of the total required human resources. Due to urgent business needs, the Company changed its strategy to meet employee needs by promoting 15 employees who are in 1 position under the Manager to fill these positions temporarily. This causes the performance of temporary officials to be not optimal because competently these employees do not have the competence required to occupy the position. Seeing this, the company took the initiative to prepare a succession planning for the company. Have a talent pool in important positions that contribute to the Company's achievements.

Based on this background, the problems that need to be analyzed in this paper are as follows How to identify talents to meet needs critical position, how do you develop the right retention plan in order to retain your talents, how to identify talent readiness to meet the needs of a critical position.

\section{Literature Review}

According to Carole Tansley (2006), talents are individuals who can make a difference to organizational performance, either through their direct contribution or in the long term by showing the highest level of potential. Talent Management according to Rampersad (2006) is a method for managing talent within an organization effectively. It includes a development plan, talent utilization and succession planning.

The definition of Talent Management according to Darmin Ahmad Pella and Afifah Inayati (2011) is a process to ensure a company fills key future leaders and positions that support the company's core competencies (unique skills and high strategic value).

Meanwhile, according to Lewis and Heckman (2006) the notion of Talent Management is an overall process starting from recruitment, placement and planning for employee development in a better direction. It can be concluded that Talent Management is a method used by organizations to identify, develop, retain talent in order to occupy key positions in a company.

According to Vince (2008) key or critical positions are positions that have a direct impact on company performance. The company consists of various positions that are carried out by the workforce and these positions must carry out the strategies that have been prepared to achieve the Company's goals. Therefore, an understanding of the level of impact that is contributed to each level can differentiate one position from another. The position that makes a big contribution is called the key or critical position.

According to Research conducted by The Procter \& Gamble Company (Corporate Leadership Council Research, 2005) identification of key positions needs to be done by conducting an assessment. against the Impact \& Complexity indicator for a position in an organization by using the questionnaire listed in Table 2.

Tabel 2. Questionnaire terkait Impact \& Complexity

\begin{tabular}{ccccccc}
\hline \multicolumn{8}{c}{$\begin{array}{c}\text { Critical role } \\
\text { Identification }\end{array}$} \\
\hline $\begin{array}{c}\text { Key } \\
\text { Questions }\end{array}$ & Very & Low & Average & High & Very High \\
\hline & Low & & & & \\
\hline
\end{tabular}

Does this position require significant

A top or bottom- line results for the business?

Is the position responsible for the 
B largest growth opportunities?

Does this position require turning

$\mathrm{C}$ around a once profitabel business?

Is this position responsible for the most

D valuable customers or brands?

Is this position responsible for the most

E critical internal audiences?

\begin{tabular}{ccccccc}
\hline \multicolumn{1}{c}{ II. Role Complexity } & & & \\
\hline $\begin{array}{c}\text { Key } \\
\text { Questions }\end{array}$ & $\begin{array}{c}\text { Very } \\
\text { Low }\end{array}$ & Low & Average & High & $\begin{array}{c}\text { Very } \\
\text { High }\end{array}$ \\
\cline { 2 - 7 } & 1 & 2 & 3 & 4 & 5 \\
\hline
\end{tabular}

\begin{tabular}{ll}
\hline $\mathrm{F} \quad \begin{array}{l}\text { Does this position require working } \\
\text { across organizational boundaries and } \\
\text { cultural challenges? }\end{array}$ \\
\hline $\mathrm{G} \quad \begin{array}{l}\text { Does this position require exercising } \\
\text { broad decision making authority? }\end{array}$ \\
\hline $\mathrm{H} \quad \begin{array}{l}\text { Does this position require developing } \\
\text { strategy or designing new products? }\end{array}$ \\
\hline & $\begin{array}{l}\text { Does this position require using a wide } \\
\text { range of skills? }\end{array}$ \\
\hline $\mathrm{J} \quad \begin{array}{l}\text { Does this position require adapting } \\
\text { work plans to changing circumstances? }\end{array}$ \\
\hline
\end{tabular}

The ratings given with a value of 1 to 5 in table 2 have each of the meanings described in tables 3 and 4 .

Table 3. Position Impact Assessment

\begin{tabular}{cll}
\hline & \multicolumn{2}{c}{ Position Impact (I. Impact on business result) } \\
\cline { 2 - 3 } Very Low & \multicolumn{1}{c}{ Do not directly manage any cost/revenue } & \multicolumn{1}{c}{ Strategic Impact } \\
\hline $\mathbf{1}$ & $\begin{array}{l}\text { No impact on strategy executionwhen } \\
\text { the job is not filled (e.g. admin staff) }\end{array}$ \\
\hline Low & $\begin{array}{l}\text { Manage }<30 \% \text { portofolio of } \\
\text { revenue or manage }<20 \% \text { of cost } \\
\text { components }\end{array}$ & $\begin{array}{l}\text { There is only indirect impact on } \\
\text { strategy execution when the job isnot filled }\end{array}$ \\
\hline $\mathbf{2}$ & $\begin{array}{l}\text { Manage } 30 \%-50 \% \text { portofolio of } \\
\text { revenue or manage } 20 \%-40 \% \text { of } \\
\text { cost components }\end{array}$ & $\begin{array}{l}\text { Create delays if vacant in longterm, } \\
\text { no impact in short term }\end{array}$ \\
\hline $\mathbf{3}$ & $\begin{array}{l}\text { Manage } 50 \%-70 \% \text { portofolio of } \\
\text { revenue or manage } 40 \%-50 \% \text { ofcost } \\
\text { components }\end{array}$ & $\begin{array}{l}\text { Create delays if vacant in both shortterm \& } \\
\text { long term }\end{array}$ \\
\hline $\mathbf{H i g h}$ & $\begin{array}{l}\text { Manage }>70 \% \text { portofolio of revenue or } \\
\text { manage }>50 \% \text { of costcomponents }\end{array}$ & $\begin{array}{l}\text { Operation stop/ create majordelays } \\
\text { in most of functions's strategy }\end{array}$ \\
\hline Very High & &
\end{tabular}

Table 4. Assessment of Complexity of skills 


\begin{tabular}{|c|c|c|c|}
\hline & & \multicolumn{2}{|c|}{ Complexity of Skill } \\
\hline & & Skill Requirement & Learning Experiences \\
\hline Very Low & \multirow{6}{*}{ Technical } & \multirow[b]{2}{*}{ Semi skilled/ unskilled employee } & \multirow{2}{*}{$\begin{array}{l}0-2 \text { years of } \\
\text { experiences }\end{array}$} \\
\hline 1 & & & \\
\hline Low & & \multirow{2}{*}{$\begin{array}{l}\text { Employee with specialized skillsor } \\
\text { equipment }\end{array}$} & \multirow{2}{*}{$\begin{array}{l}3-5 \text { years of } \\
\text { experiences }\end{array}$} \\
\hline 2 & & & \\
\hline Average & & \multirow{2}{*}{$\begin{array}{l}\text { Advanced skill worker who } \\
\text { mastery covational skill }\end{array}$} & \multirow{2}{*}{$\begin{array}{l}6-8 \text { years of } \\
\text { experiences }\end{array}$} \\
\hline 3 & & & \\
\hline High & \multirow{4}{*}{ Conceptual } & \multirow{2}{*}{$\begin{array}{l}\text { Professional qualification with } \\
\text { disciplinary understanding/ technical } \\
\text { sufficiency }\end{array}$} & \multirow{2}{*}{$\begin{array}{l}9-12 \text { years of } \\
\text { experiences }\end{array}$} \\
\hline 4 & & & \\
\hline Very High & & $\begin{array}{l}\text { Seasoned professional with } \\
\text { technical \& discinlinary }\end{array}$ & \multirow{2}{*}{$\begin{array}{l}>12 \text { years of } \\
\text { experiences }\end{array}$} \\
\hline 5 & & $\begin{array}{l}\text { technical \& disciplinary } \\
\text { proficiency \& management } \\
\text { knowledge }\end{array}$ & \\
\hline
\end{tabular}

The indicators in table 3 explain how much strategic and financial impact this position has. While the indicators in table 4 explain the positions that have unique in its abilities, difficult to master and requires a lot of investment to learn these skills.

After the assessment has been completed, the results of the assessment can be entered into table 5 to see the impact that this position has. Positions with an average score of 4 to 5 will be included in the category key or critical position (table 5).

Table 5. Key Position

\begin{tabular}{ccccc}
\hline 5 & \multicolumn{1}{c}{$\begin{array}{c}\text { Critica } \\
\text { lrole }\end{array}$} & $\begin{array}{c}\text { Critica } \\
\text { lrole }\end{array}$ & $\begin{array}{c}\text { Critica } \\
\text { lrole }\end{array}$ \\
\cline { 2 - 5 } & & & $\begin{array}{c}\text { Critica } \\
\text { lrole }\end{array}$ & $\begin{array}{c}\text { Critica } \\
\text { lrole }\end{array}$ \\
\cline { 2 - 5 } Complexity & 3 & & & $\begin{array}{c}\text { Critica } \\
\text { lrole }\end{array}$ \\
\cline { 2 - 5 } & 2 & & & \\
\cline { 2 - 5 } & & & & \\
\hline
\end{tabular}

According to The Chartered Institute of Personnel and Development (CIPD), succession planning can be defined as a process to identify and develop future leaders and even potential individuals to fill an important position, both in the short and long term. According to William Rothwell (2005), succession planning is a systematic effort made by organizations to ensure leadership in key positions continues and to encourage individual progress.

Christee Gabour Atwood (2007) explains that succession planning is having the right people in the right place at the right time. Specifically, succession planning is an ongoing process of identifying Successors in key positions within an organization and developing them so that they are ready to fill these key positions.

It can be concluded that succession planning is a systematic process that is continuously carried out to prepare successors to fill important positions in an organization.

Christee Gabour Atwood (2007) explains that succession planning is not only a process of changing important positions such as Chief Executive Officer (CEO). Succession planning is also required for leadership positions at every level in the organization. The purpose of succession planning is to prepare the organization for the challenges and opportunities associated with changing critical roles. This can be achieved by developing employees to ensure the organization has enough competent candidates to fill critical roles when those positions are vacant. 
There are several stages in implementing Succession planning according to the Victoria State Government (Education \& Training, 2019), namely: 1) Identification of a key position (critical role), 2) Compile or determine a Successor profile, 3) Assess the performance and potential of employees 4) Develop a Successor development plan, 5) Implement Successor development 6) Successors are ready to occupy important positions, 7) Review the implementation of succession planning.

\section{Table 6. Seven process stages of Succession Planning}

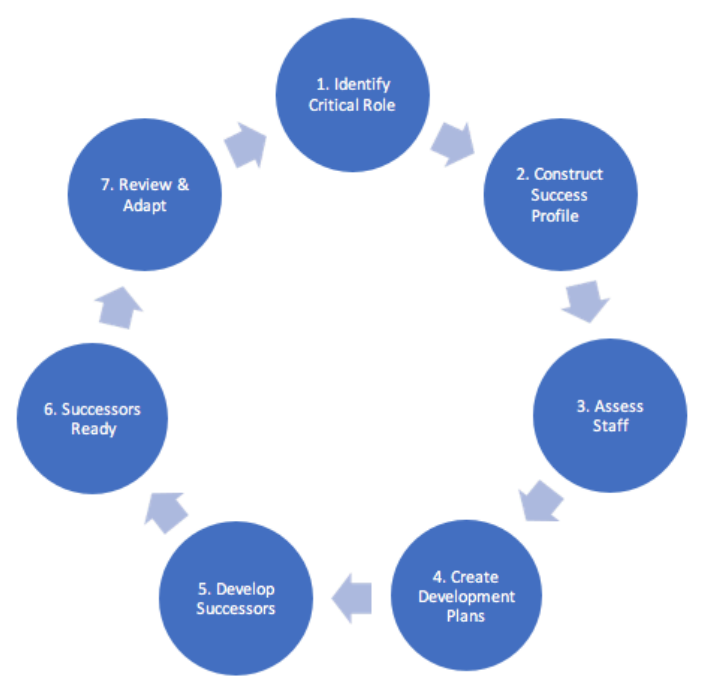

Each of these stages has contributed to its creation succession planning.

At this time the development and growth of the company PT. WOW, always followed by organizational restructuring in order to maintain sustainability between the company's business planning and the trend of the business world that continues to be dynamic.

Organizational restructuring carried out company will have an impact on a need in planning for employee needs (Manpower Planning). Manpower Planning (MPP) aims to ensure that the company has all the manpower resources needed to carry out business functions in accordance with company goals. Thus the substance of the implementation of the MPP will be related to the sustainability of the company's managerial leadership (succession planning). Development of Succession planning for Subsidiary Companies Engaged in the Insurance Sector Talent and Critical Position

The planning process for the needs of the employees of company refers to the long-term business plan contained in the Corporate Plan of company and short-term business plans that are stipulated in the Budget Work Plan (RKA) each year.

Based on data from the Manpower Planning of company position In February 2021, there is a gap to fulfill the formation of managerial positions at head office according to the table as follows:

Table 7. Manpower Planning (MPP) Manager Position

\begin{tabular}{|c|c|c|c|}
\hline Position Level & Formation & Existing & Gap \\
\hline Manager & \multirow{6}{*}{50} & \multirow{6}{*}{35} & \multirow{6}{*}{-15} \\
\hline Group Head Internal Audit & & & \\
\hline Group Head Aktuaris & & & \\
\hline Group Head Legal & & & \\
\hline Group Head Bisnis Corporate \& Retail & & & \\
\hline Group Head Underwritind \& Reinsurance & & & \\
\hline
\end{tabular}

Management requires that the fulfillment of the managerial position at the head office is carried out by developing internal employees through assignments aimed at developing Employee Competencies (Developmental Assignment). 
Based on data from the Manpower Planning of PT. WOW Head Office Work Unit for Manager Position (table 7) obtained information that there is a gap in MPP fulfillment for Manager positions as many as 15 employees.

Furthermore, the management stipulates that the fulfillment of the MPP Manager Position is carried out through Developmental Assignment as a succession candidate or internal talent who will be prepared to assume the position of Manager of the Head Office of PT. WOW with the following criteria: 1) Permanent employees who do not hold structural positions (functional staff) are equivalent to a minimum job grade 6., 2) Permanent Employees who have Employee Performance Appraisal (PKP) for 3 (three) consecutive years at least "Good" (PKP value range $\geq 2.61-3.40$ ), 3) Permanent employees who have passed the assessment with a minimum result of "recommended or moderate capacity", 4) Employees who have met these requirements (points 1-3) will be appointed as the Manager's Position (PJ) with an evaluation period of 1 (one) year, 5) The PJ Manager evaluation period is 1 (one) year as a stage to measure the level of readiness of employees to occupy a position, based on the compatibility of the competency profile, work experience, personality aspects of the employee with the requirements / specifications for the position (readiness).

Retention Planning

Mathis \& Jackson (2011) views employee retention as the company's ability to maintain and retain talented and potential employees in order to be loyal or remain loyal to work in the company. In other words, employee retention is intended to prevent quality employees from leaving the company on the employee's own wish.

\section{METHODS}

In this study using the Qualitative Phenomenology Method, the purpose of this study is to provide input regarding the proper retention plan formulation procedures and provide input regarding the procedures for identifying talent readiness to meet the needs of a critical position.

Table 8. Position Impact Assessment

\begin{tabular}{cll}
\hline & \multicolumn{1}{c}{ Position Impact (I. Impact on business result) } \\
\cline { 2 - 3 } Very Low & \multicolumn{1}{c}{ Do not directly manage any cost/revenue } & \multicolumn{1}{c}{ Strategic Impact } \\
\hline $\mathbf{1}$ & $\begin{array}{l}\text { No impact on strategy executionwhen } \\
\text { the job is not filled (e.g. admin staff) }\end{array}$ \\
\hline Low & $\begin{array}{l}\text { Manage }<30 \% \text { portofolio of } \\
\text { revenue or manage }<20 \% \text { of cost } \\
\text { components }\end{array}$ & $\begin{array}{l}\text { There is only indirect impact on } \\
\text { strategy execution when the job isnot filled }\end{array}$ \\
\hline $\mathbf{2}$ & $\begin{array}{l}\text { Manage } 30 \%-50 \% \text { portofolio of } \\
\text { revenue or manage } 20 \%-40 \% \text { of } \\
\text { cost components }\end{array}$ & $\begin{array}{l}\text { Create delays if vacant in longterm, } \\
\text { no impact in short term }\end{array}$ \\
\hline $\mathbf{3}$ & $\begin{array}{l}\text { Manage } 50 \%-70 \% \text { portofolio of } \\
\text { revenue or manage 40\%-50\% ofcost } \\
\text { components }\end{array}$ & $\begin{array}{l}\text { Create delays if vacant in both shortterm \& } \\
\text { long term }\end{array}$ \\
\hline $\mathbf{4}$ & $\begin{array}{l}\text { Manage }>70 \% \text { portofolio of revenue or } \\
\text { manage }>50 \% \text { of costcomponents }\end{array}$ & $\begin{array}{l}\text { Operation stop/ create majordelays } \\
\text { in most of functions's strategy }\end{array}$ \\
\hline Very High &
\end{tabular}

Table 9. Assessment of Complexity of skills

\begin{tabular}{cccc}
\hline & & \multicolumn{2}{c}{ Complexity of Skill } \\
Very Low & & Skill Requirement & Learning Experiences \\
\hline $\mathbf{1}$ & & Semi skilled/ unskilled employee & $\begin{array}{l}0-2 \text { years of } \\
\text { experiences }\end{array}$ \\
Low & \multirow{2}{*}{ Technical } & $\begin{array}{l}\text { Employee with specialized skillsor } \\
\text { equipment }\end{array}$ & $\begin{array}{l}\text { 3-5 years of } \\
\text { experiences }\end{array}$ \\
\hline
\end{tabular}




\begin{tabular}{clll}
\hline Average & & $\begin{array}{l}\text { Advanced skill worker who } \\
\text { mastery covational skill }\end{array}$ & $\begin{array}{l}\text { 6-8 years of } \\
\text { experiences }\end{array}$ \\
\hline High & & $\begin{array}{l}\text { Professional qualification with } \\
\text { disciplinary understanding/ technical } \\
\text { sufficiency }\end{array}$ & $\begin{array}{l}\text { 9-12 years of } \\
\text { experiences }\end{array}$ \\
\cline { 1 - 1 } Very High & Conceptual & $\begin{array}{l}\text { Seasoned professional with } \\
\text { technical \& disciplinary } \\
\text { proficiency \& management } \\
\text { knowledge }\end{array}$ & $\begin{array}{l}\text { >12 years of } \\
\text { experiences }\end{array}$ \\
\hline
\end{tabular}

The indicators in table 3 explain how much strategic and financial impact this position has. While the indicators in table 4 explain the positions that have unique in its abilities, difficult to master and requires a lot of investment to learn these skills.

Talent Identification

Management has determined that the fulfillment of talent in the position of Manager at the head office will be carried out through a Developmental Assignment, namely the assignment of employees to their current positions with the aim of developing employee competencies according to the objectives of their positions.

Based on this, the company, in this case the Human Resources Division will carry out the process of identifying talent within the Company based on the measurement of the performance aspect of the talent (performance) and the measurement of the aspect of capacity (capacity).

Measurement of Talent Performance Aspects (Performance)

Measuring aspects of the talent performance (Performance) of is based on the Worker Performance Assessment System (PKP) for the last 3 (three) years, which is categorized as follows, 1) Exceed Performance, if the Employee has received an average PKP Value for the last 3 (three) years, the lowest is

3.41 (three point four one), 2) Meet Performance, if the employee gets the average PKP value for the last 3 (three) years within the range of values

2.61 (two point six one) up to the value of 3.40 (three point four zeros), 3) Below Performance, if the Employee has received the average PKP value for the last 3 (three) years, which is lower or equal to 2.60 (two point sixty).

The categorization of the above aspects of talent performance can be adjusted to the needs of the Company based on the decision of the Talent Committee. According to the Manpower Planning data Head Office Work Unit for Manager Position, there is a gap in MPP fulfillment for Manager positions as many as 15 employees. Fulfilling the MPP position gap will be prepared from the allocation of functional staff at grade 6 level or one position below the Manager. These functional staff are talents who have met the criteria for Worker Performance Appraisal (PKP) for 3 (three) consecutive years at least "Good" (PKP value range $\geq 2.61$ - 3.40).

Table 10. Worker Performance Assessment (PKP) Grade 6 Functional Staff

\begin{tabular}{cccccccc}
\hline \multirow{2}{*}{ Num } & \multirow{2}{*}{ Name } & Position & Grade & \multicolumn{5}{c}{ Worker Performance Appraisal } \\
\cline { 5 - 8 } & & & $\mathbf{2 0 1 8}$ & $\mathbf{2 0 1 9}$ & $\mathbf{2 0 2 0}$ & Average \\
\hline 1 & MMM & Staf & 6 & 3,82 & 3,49 & 3,90 & 3,737 \\
\hline 2 & EEE & Staf & 6 & 3,82 & 3,60 & 3,75 & 3,723 \\
\hline 3 & JJJ & Staf & 6 & 3,72 & 3,79 & 3,55 & 3,687 \\
\hline 4 & AAA & Staf & 6 & 3,55 & 3,60 & 3,90 & 3,683 \\
\hline 5 & III & Staf & 6 & 3,55 & 3,63 & 3,82 & 3,667 \\
\hline 6 & KKK & Staf & 6 & 3,48 & 3,85 & 3,60 & 3,643 \\
\hline 7 & DDD & Staf & 6 & 3,70 & 3,45 & 3,72 & 3,623 \\
\hline 8 & LLL & Staf & 6 & 3,46 & 3,55 & 3,85 & 3,620 \\
\hline 9 & OOO & Staf & 6 & 3,48 & 3,50 & 3,85 & 3,610 \\
\hline 10 & BBB & Staf & 6 & 3,60 & 3,65 & 3,55 & 3,600 \\
\hline 11 & GGG & Staf & 6 & 3,68 & 3,40 & 3,69 & 3,590 \\
\hline 12 & HHH & Staf & 6 & 3,49 & 3,55 & 3,73 & 3,590 \\
\hline 13 & NNN & Staf & 6 & 3,65 & 3,67 & 3,40 & 3,573 \\
\hline 14 & FFF & Staf & 6 & 3,49 & 3,65 & 3,55 & 3,563 \\
\hline 15 & CCC & Staf & 6 & 3,55 & 3,48 & 3,60 & 3,543 \\
\hline
\end{tabular}

Measurement of Capacity Aspects (Capacity) 
Company conducts capacity measurements in collaboration with Assessment Center vendors which aim to predict the potential of each talent to be developed as a successor for a particular position. Measurement of the capacity aspect is categorized as follows; 1) High Capacity, if the Employee receives a recommendation from the Assessment Center "Highly Recommended", with the criteria of meeting all the required competencies, or there are a maximum of 2 competencies with a gap (-1) in competencies other than core competencies (total competencies with a maximum negative gap of 2), 2) Moderate capacity, if the employee gets a "Recommended" Assessment Center recommendation, with the criteria there is a maximum of 1 competency with a gap (-1) in core competencies (other than Integrity competencies) and a maximum of 2 competencies with a gap (-1) on other competencies, or There are a maximum of 3 competencies with a gap (-1) in competencies other than core competencies (total competencies with a maximum negative gap of 3), 3) Low Capacity, if the employee gets a recommendation from the "Not Recommended" Assessment Center, with the criteria that there is a maximum of 1 competency with a gap (-2), or there are a maximum of 2 competencies with a gap (-1) in the core competency and a maximum of two competencies with a gap ( -1) for other competencies, or there are a maximum of 4 competencies with a gap (-1) in competencies other than core competencies (total competencies with a maximum negative gap of 4 ).

Table 11. Generic Competencies of Manager Position in the company

\begin{tabular}{|c|c|c|c|}
\hline \multirow{2}{*}{\multicolumn{3}{|c|}{$\begin{array}{l}\text { Num Competency Required Level } \\
\text { CORE COMPETENCY } \\
\end{array}$}} & \multirow[t]{2}{*}{ Description } \\
\hline & & & \\
\hline 1 & $\begin{array}{l}\text { Encouragement } \\
\text { for } \\
\text { Achievement }\end{array}$ & 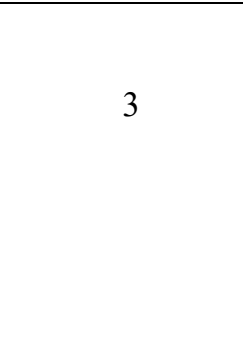 & $\begin{array}{l}\text { Establish and work towards challenging goals: } \\
\text { 1. Setting challenging goals, which are difficult but } \\
\text { still possible to achieve } \\
\text { 2. Compare specifically the presence of a } \\
\text { significant increase in performance over a } \\
\text { period of time } \\
\text { 3. Determined to achieve a unique standard, which } \\
\text { has not been accomplished before. }\end{array}$ \\
\hline 2 & $\begin{array}{l}\text { Customer } \\
\text { Service } \\
\text { Orientation }\end{array}$ & 3 & $\begin{array}{l}\text { Doing more for customers: } \\
\text { 1. Be available at all times to help customers, } \\
\text { especially when the customer has a critical } \\
\text { problem, for example spending extra time and } \\
\text { effort at the customer's location } \\
\text { 2. Go beyond what customers expect } \\
\text { 3. Take concrete actions that add value to } \\
\text { customers }\end{array}$ \\
\hline
\end{tabular}

Be ethically consistent even when it is difficult:

1. Act consistently against insurance policies and ethics, even in difficult circumstances

3 Integrity (INT) $3 \quad$ 2. Dare to openly admit mistakes

3. Dare to talk about unethical behavior. Even if it carries a significant risk to him or his employees

4. Ensuring full transparency in a deal, with mention costs and constraints, as well as benefits

\begin{tabular}{|c|c|c|}
\hline \multirow{2}{*}{\multicolumn{2}{|c|}{$\begin{array}{l}\text { Num Competency } \quad \text { Required Level } \\
\text { OTHER COMPETENCIES }\end{array}$}} & \multirow[t]{2}{*}{ Description } \\
\hline & & \\
\hline \multirow[t]{4}{*}{ Leadership } & & Protecting group: \\
\hline & 3 & 1. Protect the group and its reputation \\
\hline & & $\begin{array}{l}\text { 2. Ensuring the group's practical needs are met, } \\
\text { getting the right people, resources and } \\
\text { information }\end{array}$ \\
\hline & & $\begin{array}{l}\text { 3. Provide or ensure support and development for } \\
\text { group members and the group as a whole }\end{array}$ \\
\hline
\end{tabular}

Briefing: 


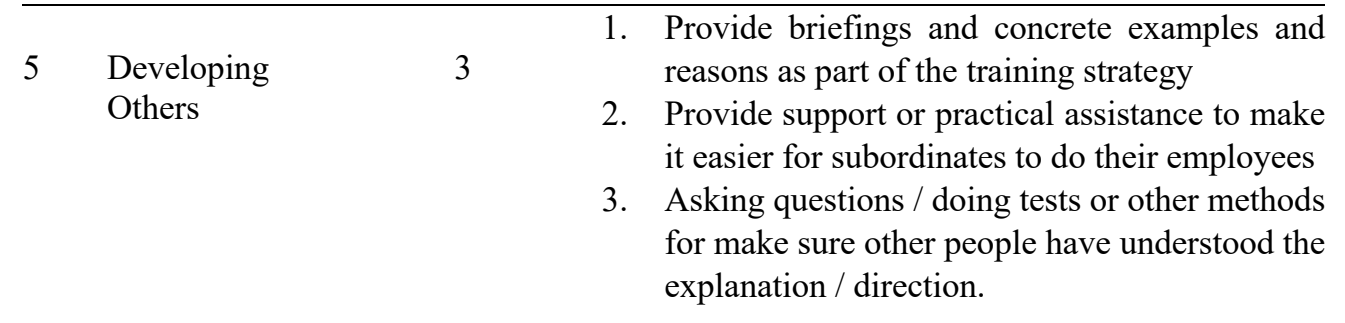

\begin{tabular}{|c|c|c|c|}
\hline 6 & $\begin{array}{l}\text { Conceptual } \\
\text { Thinking }\end{array}$ & 3 & $\begin{array}{l}\text { Describe a complex situation } \\
\text { 1. Make ideas or complex situations clear, simple } \\
\text { and easy to understand } \\
\text { 2. Combining various ideas, problems and } \\
\text { observations into a meaningful explanation. } \\
\text { Convey existing observations or knowledge in a } \\
\text { simpler way } \\
\text { 3. Combining ideas and other information and } \\
\text { creating a deeper picture big becomes more } \\
\text { complete and clear (biggir picture) }\end{array}$ \\
\hline 7 & $\begin{array}{l}\text { Affecting } \\
\text { Others }\end{array}$ & 3 & $\begin{array}{l}\text { Using indirect influence } \\
\text { 1. Using a series of indirect influences so that the } \\
\text { message giver's goals are achieved. } \\
\text { 2. Take action to influence, each step is adapted to } \\
\text { the circumstances } \\
\text { 3. Utilizing experts or third parties to influence. }\end{array}$ \\
\hline 8 & Initiative & 3 & $\begin{array}{l}\text { Take } 4-12 \text { months of anticipatory action: anticipate } \\
\text { and act on opportunities or problems in the next } 4 \text { to } \\
12 \text { months }\end{array}$ \\
\hline 9 & $\begin{array}{l}\text { Concern for } \\
\text { Quality \& } \\
\text { Accuracy }\end{array}$ & 3 & $\begin{array}{l}\text { 1. Monitor the quality of other people's employees } \\
\text { 2. Checks whether the procedure has been } \\
\text { followed } \\
\text { 3. Document clearly and in detail about the } \\
\text { activities of oneself and others. }\end{array}$ \\
\hline 10 & $\begin{array}{l}\text { Information } \\
\text { Search }\end{array}$ & 3 & $\begin{array}{l}\text { 1. Make efforts systematically / research } \\
\text { 2. Make systematic efforts within a limited period } \\
\text { of time to obtain the most up-to-date } \\
\text { information on industry, political, economic } \\
\text { and technological trends as well as development } \\
\text { of relevant information for BRI Insurance } \\
\text { 3. Conducting formal research through } \\
\text { information presented in newspapers, } \\
\text { magazines, computer networks or other sources, } \\
\text { including on research on markets, finances and } \\
\text { competitors. }\end{array}$ \\
\hline
\end{tabular}

Table 9 describes 10 generic competencies that must be fulfilled by the Manager Position with the required level of each competency (required level) at level 3.

The 10 competencies for the position of Manager are divided into 2 types of core competency categories and all other required competencies. Core competencies consist of Achievement Encouragement, Customer Service Orientation and Integrity, while other competencies consist of Leadership Developing others, Conceptual Thinking, Influencing Others, Initiative, Concern for Quality and Accuracy and Information Seeking.

Talent Mapping

The company conducts employee performance appraisals using the Performance $\mathrm{x}$ Potential Matrix Table which is divided into 9 quadrants (table 10).

\section{Tabel 12. Performance $x$ Potential Matrix}




\begin{tabular}{|c|c|c|}
\hline High Professional & Emerging Talent & Top Talent \\
\hline $\begin{array}{l}\text { Consistently produces } \\
\text { exceptional results and high } \\
\text { performance ratings. } \\
\text { Individuals with highly } \\
\text { valued technical/functional } \\
\text { skills in their area of } \\
\text { expertise; often have deep } \\
\text { history of their area and/or } \\
\text { the organization. Could } \\
\text { assume larger } \\
\text { responsibilities but may } \\
\text { have chosen career path } \\
\text { that leverages expertise } \\
\text { rather than moving to } \\
\text { broader experiences. } 4 \\
\text { Tend to be good developers } \\
\text { of others. }\end{array}$ & $\begin{array}{l}\text { Consistently produces } \\
\text { exceptional results and } \\
\text { receives high performance } \\
\text { ratings. Can adapt to new } \\
\text { situations and learn new areas. } \\
\text { Is promotable in multiple } \\
\text { functional/technical areas or } \\
\text { general management. }\end{array}$ & $\begin{array}{l}\text { The best talent you have; } \\
\text { typically in short supply but high } \\
\text { demand. Performs well in } \\
\text { almost everything they take on. } \\
\text { Learns fast. Transfers learning } \\
\text { from one area to another. Gets } \\
\text { things done under tight } \\
\text { deadlines. Can take on major } \\
\text { stretch assignments. Can be } \\
\text { promoted or moved laterally } \\
\text { into just about any situation. A } \\
\text { role model for inspiring and } \\
\text { developing people with unique } \\
\text { and diverse insights and } \\
\text { experiences. }\end{array}$ \\
\hline Highly Valued Contributor & Key Performer & Rising Star \\
\hline $\begin{array}{l}\text { A valued member of the team. } \\
\text { Consistently meets and } \\
\text { occasionally exceeds } \\
\text { expectations. Knows current } \\
\text { job well and could apply } \\
\text { knowledge and experience to } \\
\text { similar roles within Kraft. A } \\
\text { position move would likely be } \\
\text { in a similar area. Could } \\
\text { progress higher in a specialist } \\
\text { role and become a High } \\
\text { Professional. Could enhance } \\
\text { potential and become a Key } \\
\text { Performer. }\end{array}$ & $\begin{array}{l}\text { A valued member of the team. } \\
\text { Consistently meets and } \\
\text { occasionally exceeds } \\
\text { expectations. Understands and } \\
\text { knows the current job well and } \\
\text { enhances skills for their } \\
\text { current job as well as the near } \\
\text { term future. Can adapt to new } \\
\text { situations and challenges as } \\
\text { necessary. Comfortably } \\
\text { assumes new jobs and roles } \\
\text { and performs well in them in } \\
\text { time. Likely promotable a level } \\
\text { vertically or could move } \\
\text { laterally within the5 } \\
\text { organization. }\end{array}$ & $\begin{array}{l}\text { A valued member of the team. } \\
\text { Consistently meets and } \\
\text { occasionally exceeds } \\
\text { expectations. Has the capacity } \\
\text { to take on new and different } \\
\text { challenges on a consistent basis. } \\
\text { Addresses new challenges and } \\
\text { issues with ease. Quickly gets up } \\
\text { to speed when taking on a new } \\
\text { assignment. Has the potential to } \\
\text { make career changes into } \\
\text { different situations. Effectively } \\
\text { inspires and develops people } \\
\text { with unique and diverse insights } \\
\text { and experiences. }\end{array}$ \\
\hline Lower Performer & Inconsistent Performer & Emerging Performer \\
\hline $\begin{array}{l}\text { Is not delivering results as } \\
\text { expected and cannot } \\
\text { effectively adapt to new and } \\
\text { different situations. This is the } \\
\text { least valued cell in terms of } \\
\text { ROI. Occupants of this cell may } \\
\text { require performance action. }\end{array}$ & $\begin{array}{l}\text { (Potential Key Performer) } \\
\text { Is a valued contributor with } \\
\text { potential but is not meeting } \\
\text { performance expectations in } \\
\text { current role. May be in the } \\
\text { wrong job or a poor fit for the } \\
\text { current situation. }\end{array}$ & $\begin{array}{l}\text { (Potential Rising Star) } \\
\text { Have the potential to perform } \\
\text { exceptionally well, but the } \\
\text { actual playing out of the } \\
\text { potential is in the future. They } \\
\text { may have been inconsistent in } \\
\text { the past or may have had one or } \\
\text { more significant stumbles } \\
\text { recently but still considered to } \\
\text { have the potential to be a } \\
\text { significant contributor. }\end{array}$ \\
\hline
\end{tabular}

\section{POTENTIAL}


Based on the talent identification process in the Company which is based on the measurement of the aspect of talent performance (Performance) and the measurement of the aspect of capacity (Capacity), a list of Successors for the Position of Manager is obtained from 15 grade 6 functional staff as follows:

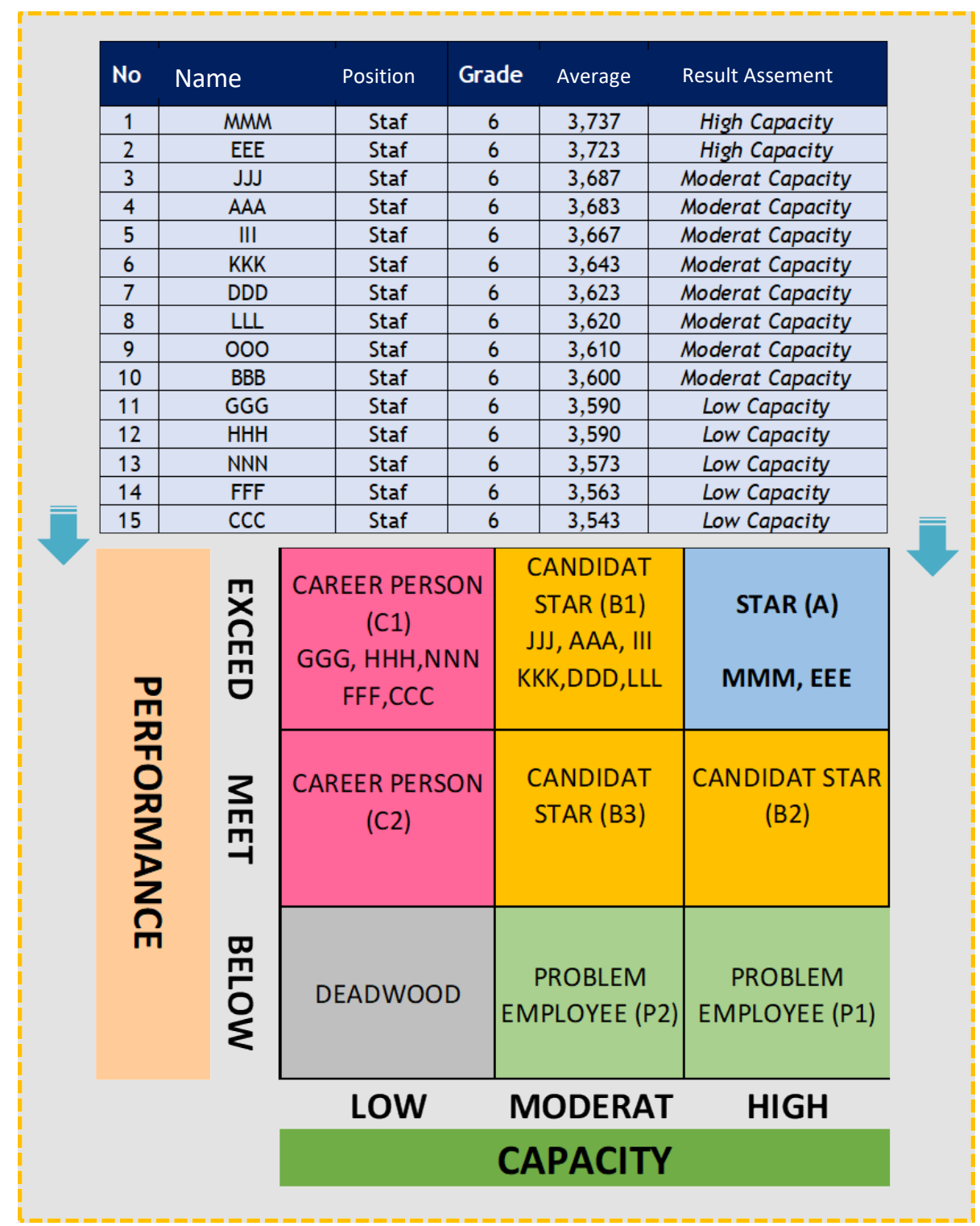

Picture 1. Illustration of table 10

In the illustration of table 10 above, an illustration shows that from the 15 list of Successors for Manager positions, there are 2 talents with Average rank "Very Good" with a "High Capacity" capacity, 8 talents with Average rankings with a "Moderate Capacity" capacity, and 5 people. talent with Average rating with "Low Capacity" capacity.

As for the results of the Assessment Center recommendations in table 11, for the needs of Talent Succession for the Position of Manager of company which comes from internal talent of Grade 6 Functional Staff, can be grouped as follows:

Table 13. Matrix of Grade 6 Functional Staff Successor Readiness List

\begin{tabular}{ll}
\hline Recommended & Readiness Category \\
\hline $\begin{array}{l}\text { Highly recommended (High } \\
\text { Capacity) }\end{array}$ & $\begin{array}{l}\text { Ready Now } \\
\text { (Ready to be promoted now, or requires relatively short- } \\
\text { term development) }\end{array}$ \\
\hline $\begin{array}{l}\text { Recommended } \\
\text { (Moderate Capacity) }\end{array}$ & $\begin{array}{l}\text { Ready with Development } \\
\text { (Requires moderate development) }\end{array}$ \\
\hline
\end{tabular}


No Recommended (Low Capacity) Not Ready Yet

(Requires development with a longer timeframe)

Development Planning

Based on the analysis of the application of succession planning PT. WOW above, it is possible to identify the competency gap (required level) which is required with the objective of the intended position, so that the competency development method for each successor list can be obtained. The successor list competency development method will be adjusted to the needs of each talent development plan, so that in the future an Individual Development Plan (IDP) can be drawn up for each talent.

Table 14. Development Plan Successor List (continued)

\begin{tabular}{|c|c|c|c|c|c|c|c|c|}
\hline Num & $\begin{array}{l}\text { Name } \\
\text { Talent }\end{array}$ & CATEGORY & COMPETENCY & $\begin{array}{l}\text { REQUIRED } \\
\text { LEVEL }\end{array}$ & $\begin{array}{l}\text { INDIVIDUAL } \\
\text { LEVEL }\end{array}$ & DEVELOPMENT PLAN & $\begin{array}{c}\text { TIME } \\
\text { ESTIMATED }\end{array}$ & $\begin{array}{c}\text { TALENT } \\
\text { READINESS }\end{array}$ \\
\hline \multirow{4}{*}{1} & \multirow{4}{*}{ MMM } & \multirow{9}{*}{$\operatorname{STAR}(A)$} & \multirow{4}{*}{ Information Search } & \multirow{4}{*}{3} & \multirow{4}{*}{2} & 1. Public Training: Gathering Information & 1 Month & \multirow{4}{*}{6 Month } \\
\hline & & & & & & $\begin{array}{l}\text { 2. Coaching, Mentoring, Counseling carried out by } \\
\text { superiors or experienced people }\end{array}$ & 2 Month & \\
\hline & & & & & & 3. On the job training, Special Assignment & 2 Month & \\
\hline & & & & & & 4. Do assessment & & \\
\hline \multirow{5}{*}{2} & \multirow{5}{*}{ EEE } & & Conceptual thinking & 3 & 2 & 1. Public Training : Conceptual Thinking & 1 Month & \multirow{5}{*}{10 Month } \\
\hline & & & Information Search & 3 & 2 & 2. Public Training : Gathering Information & 1 Month & \\
\hline & & & & & & $\begin{array}{l}\text { 3. Coaching, Mentoring, Counseling conducted by } \\
\text { superiors or experienced people }\end{array}$ & 4 Month & \\
\hline & & & & & & 4. On the job training, Special Assignment & 4 Month & \\
\hline & & & & & & 5. Do assessment & & \\
\hline \multirow{6}{*}{3} & \multirow{6}{*}{ נJנ } & \multirow{18}{*}{ STAR (B1) } & Influencing Other People & 3 & 2 & 1. Inhouse Training : Influencing Others & 1 Month & \multirow{6}{*}{$\begin{array}{l}1 \text { year } \\
3 \text { month }\end{array}$} \\
\hline & & & Intiative & 3 & 2 & 2. Public Training : Initiative & 1 Month & \\
\hline & & & $\begin{array}{l}\text { Care for } \\
\text { Quality \& Regularity }\end{array}$ & 3 & 2 & 3. Inhouse Training : Care to Ordinary & 1 Month & \\
\hline & & & & & & $\begin{array}{l}\text { 4. Coaching, Mentoring, Counseling } \\
\text { done by superiors or experienced people }\end{array}$ & 6 Month & \\
\hline & & & & & & 5. On the job training, Special Assignment & 6 Month & \\
\hline & & & & & & 6.Do assessment & & \\
\hline \multirow{6}{*}{4} & \multirow{6}{*}{ AAA } & & $\begin{array}{l}\text { Encouragement for } \\
\text { Achievement }\end{array}$ & 3 & 2 & 1. Inhouse Training : Achievement Orientation & 1 Month & \multirow{6}{*}{$\begin{array}{l}1 \text { year } \\
3 \text { Month }\end{array}$} \\
\hline & & & Influencing Other People & 3 & 2 & 2. Inhouse Training : Influencing Others & 1 Month & \\
\hline & & & $\begin{array}{l}\text { Care for } \\
\text { Quality \& Regularity }\end{array}$ & 3 & 2 & 3. Inhouse Training : Care to Ordinary & 1 Month & \\
\hline & & & & & & $\begin{array}{l}\text { 4. Coaching, Mentoring, Counseling } \\
\text { done by superiors or experienced people }\end{array}$ & 6 Month & \\
\hline & & & & & & 5. On the job training, Special Assignment & 6 Month & \\
\hline & & & & & & 6. Do assessment & & \\
\hline \multirow{6}{*}{5} & \multirow{6}{*}{ III } & & $\begin{array}{l}\text { Encouragement for } \\
\text { Achievement }\end{array}$ & 3 & 2 & 1. Inhouse Training : Achievement Orientation & 1 Month & \multirow{6}{*}{$\begin{array}{l}1 \text { year } \\
3 \text { Month }\end{array}$} \\
\hline & & & Leadership & 3 & 2 & 2. Public Training : Leadership & 1 Month & \\
\hline & & & $\begin{array}{l}\text { Care for } \\
\text { Quality \& Regularity }\end{array}$ & 3 & 2 & 3. Inhouse Training : Care to Ordinary & 1 Month & \\
\hline & & & & & & 4. Coaching, Mentoring, Counseling conducted by & 6 Month & \\
\hline & & & & & & 5. On the job training, Special Assignment & 6 Month & \\
\hline & & & & & & 6. Do assessment & & \\
\hline \multirow{2}{*}{ NO } & NAMA & \multirow{2}{*}{ CATEGORY } & \multirow{2}{*}{ COMPETENCY } & REQUIRED & INDIVIDUAL & DFVEIOPMFNT PIAN & TIME & TALENT \\
\hline & TALENT & & & LEVEL & LEVEL & DEVELU RVIEINI PLAIN & ESTIMATED & READINESS \\
\hline & & & Customer Service Orientation & 3 & 2 & 1. Public Training : Customer Service Oriented & 1 Month & \\
\hline & & & Influencing Other People & 3 & 2 & 2. Inhouse Training : Influencing Others & 1 Month & \\
\hline & & & $\begin{array}{l}\text { Concern for quality \& } \\
\text { regularity }\end{array}$ & 3 & 2 & 3. Inhouse Training : Care to Ordinary & 1 Month & \\
\hline 6 & ККK & & & & & $\begin{array}{l}\text { 4. Coaching, Mentoring, Counseling conducted by } \\
\text { superiors or experienced people }\end{array}$ & 6 Month & $\begin{array}{l}1 \text { year } \\
3 \text { month }\end{array}$ \\
\hline & & & & & & 5. On the job training, Special Assignment & 6 Month & \\
\hline & & & & & & 6. Do assessment & & \\
\hline & & & Customer Service & & & & & \\
\hline & & & Orientation & 3 & 2 & 1. Public Training : Customer Service Oriented & 1 Month & \\
\hline & & STAR (B1) & Strategic Thinking & 3 & 2 & 2. Public Training : Strategic Thinking & 1 Month & \\
\hline & & & Conceptual thinking & 3 & 2 & 3. Public Training : Conceptual Thinking & 1 Month & \\
\hline & BBB, & & Influencing Other People & 3 & 2 & 4. Inhouse Training : Influencing Others & 1 Month & \\
\hline 7 & $\begin{array}{l}\text { DDD, } \\
\text { LLL, }\end{array}$ & & & & & $\begin{array}{l}\text { 5. Coaching, Mentoring, Counseling conducted by } \\
\text { superiors or experienced people }\end{array}$ & 8 month & $\begin{array}{l}1 \text { year } \\
8 \text { month }\end{array}$ \\
\hline & 000 & & & & & 6. On the job training, Special Assignment & 8 month & \\
\hline & & & & & & 7. Do assessment & & \\
\hline
\end{tabular}




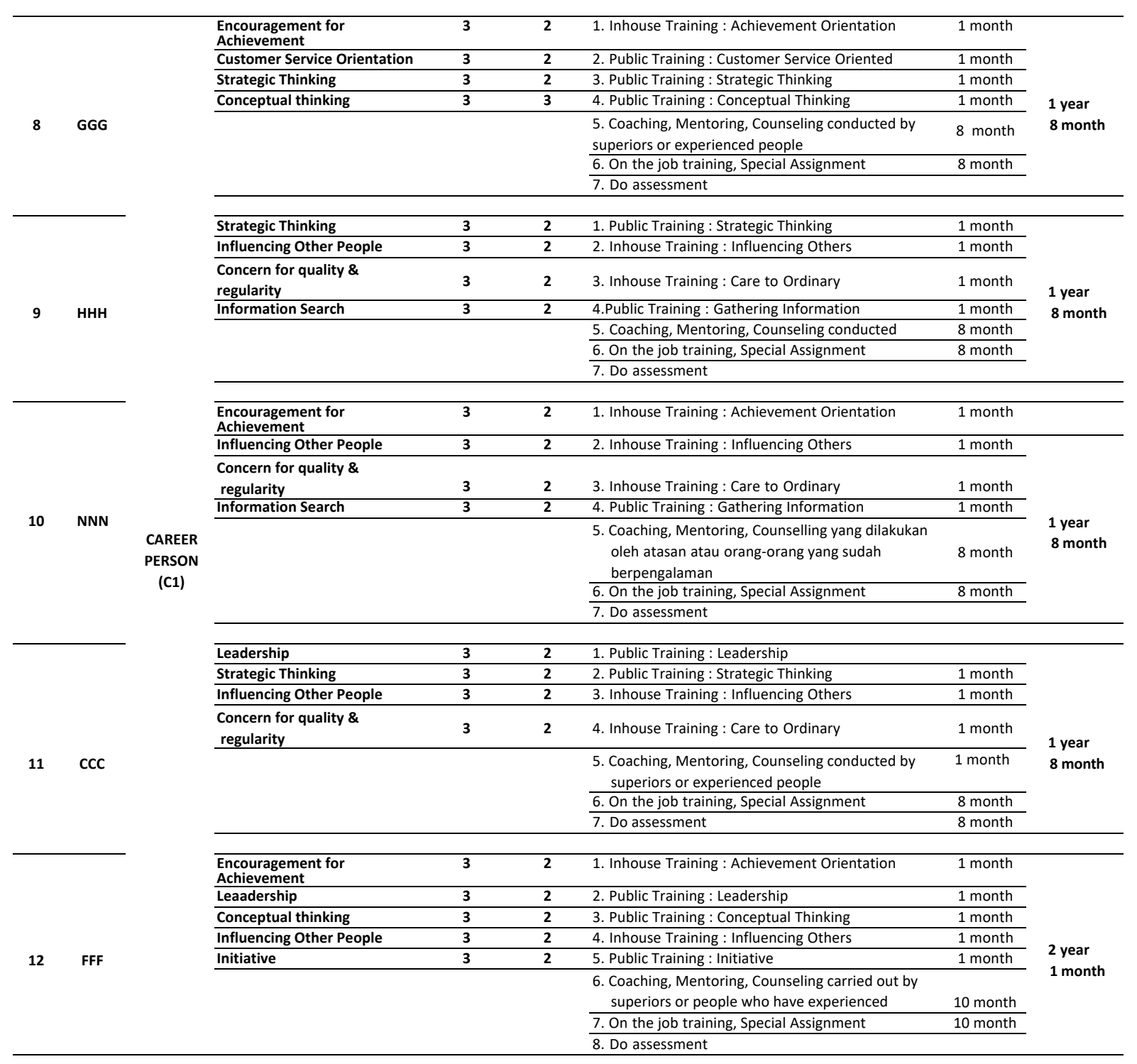

Based on the illustration in table 12 above, it can be seen that the competency development planning method is adjusted to the respective successor list segmentation category, so that the entire successor list has different readiness levels.

The development plan for each successor list can be explained as follows: Employees in the "Star (A)" category, namely employees who are currently ready to be promoted, but still require competency development with a relatively short term of less than 1 (one) year. The development plan that is carried out includes formal learning (1-3 modules / month according to the number of competency gaps), coaching and mentoring (each formal learning module / 2 months) and on the job learning by experience for 6 months, 2) Employees with the "Star (B1)" category, namely employees who require competency development with a relatively moderate period of time between 1 (one) year to 2 (two) years. The development plan that is carried out includes formal learning (3-4 modules / month according to the number of competency gaps), coaching and mentoring (each formal learning module / 2 months) and on the job learning by experience for 6-8 months, 3) Employees in the "Star (B2)" category, namely employees who require competency development with a longer period of time between 2 (two) years to 3 (three) years. The development plan that is carried out includes formal learning (4-5 modules / month according to the competency gap), coaching and mentoring (each formal learning module / 2 months) and on the job learning by experience for 8-10 months.

Retention Planning

The retention plan carried out by company can be explained in table 14 as follows: 
Tabel 15. Retention Plan

\begin{tabular}{lll}
\hline Num & Retention Program & Description \\
\hline 1. & Career development & $\begin{array}{l}\text { There are opportunities or career development opportunities transparent } \\
\text { and planned talent based on performance appraisal and potential value }\end{array}$ \\
\hline 2. & Leadership program & $\begin{array}{l}\text { to further hone leadership skills talent so that they can be prepared for a } \\
\text { higher career ladder in the future. }\end{array}$ \\
\hline 3. & $\begin{array}{l}\text { The climate and patterns of effective and conducive communication so } \\
\text { that every employee can better understand each other. Build a sense of } \\
\text { kinship among employees by conducting several events such as family } \\
\text { gathering, employee gathering, sharing day, etc. }\end{array}$ \\
\hline 4. & Role model leader & $\begin{array}{l}\text { An inspirational leader and can be used as a role model or role model } \\
\text { for the employee team and the team under him in particular. Leaders } \\
\text { who with open arms are willing to do coaching, mentoring and } \\
\text { counseling and motivate talents to achieve the goal. }\end{array}$ \\
\hline 5. & Recognition (employee & $\begin{array}{l}\text { Provide opportunities for outstanding talents to become a brand } \\
\text { ambassador for the company. }\end{array}$ \\
\hline & recognition) & $\begin{array}{l}\text { a. Provide competitive compensation value. } \\
\text { b. Providing attractive rewards and able to accommodate the needs of } \\
\text { talents and their families, such as family vacations, home ownership } \\
\text { loans with } 0 \% \text { interest, educational programs or scholarships for } \\
\text { children, health insurance with higher premiums, annual leave of more } \\
\text { than 12 days a day, a year, work life balance, etc. }\end{array}$ \\
\hline
\end{tabular}

The retention plan carried out by PT. WOW is not only limited to providing compensation in the financial aspect, but PT. WOW realizes that there are things that are psychological (non-financial aspects) such as work comfort, feeling valued, having a clear view of the Company's goals, etc. that can improve employee bounding so that the Company will not lose the talents it has developed.

\section{CONCLUSION AND RECOMMENDATION}

Based on the analysis of the application of succession planning PT. WOW, we can conclude the following: 1) The implementation of succession planning at the subsidiary company has not been carried out optimally because it is still at the create development plans stage or the $4^{\text {th }}$ stage of the seven stages of the succession planning process, 2) However, the Company is mature enough in identifying the talent and talent mapping of 15 manager candidates so that 2 candidates are in the Ready Now category, 8 candidates in the Ready With Development category and 5 candidates in the Not Ready Yet category, 3) For the candidates mentioned above, the Company has also drawn up a talent development strategy, which includes a number of development programs, including in-house training, coaching and mentoring, as well as special assignments, 4) The development program is adjusted to the proficiency level of each candidate, based on the results of an assessment conducted by the Company. The output of the development program carried out is a number of talent readiness to fill critical positions in the Company. Based on the analysis that has been done, the talent readiness of the subsidiary company ranges from 1-2 years, 5) To retain the talents already owned by the Company, the Company has also prepared a retention planning strategy. The retention strategy undertaken by the Company is more aimed at improving bounding with employees and to retain quality employees, 6) Retention efforts undertaken by the company include clear and directed career development programs, leadership programs, building open and comfortable communication patterns with employees, employee recognition, and various employee welfare programs, 7) With the development of proper succession planning and supported by effective retention planning efforts, the Company will be able to supply competent human resources and have a supply of talent to fill the needs of critical positions in the future.

\section{REFERENCES}

Ahmad Pella, Darmin \& Inayati, Afifah. 2011. Talent Management: Mengembangkan SDM untuk Mencapai Pertumbuhan dan Kinerja Prima. Jakarta: Gramedia Pustaka utama.

Atwood, Christee Gabour. 2007. Succession Planning Basic. USA : ATD Press.

Cannon, James A. \& McGee, Rita. 2011. Talent Management \& Succession Planning. UK : The Chartered 
Institute of Personnel and Development.

Lewis, R.E. \& Hackman, R.J. (2006). Talent management: A critical review. USA : Personnel Decisions International.

Rampersad, H. K. (2006). Personal Balance Scorecard: The Way to Individual Happiness, Personal Integrity and Organization Effectiveness. United States: McGraw-Hill Education.

Tansley, Carole. 2011. Industrial and Commercial Training. London : Emerald Group Publishing Limited.

The Procter \& Gamble Company. 2005. Corporate Leadership Council Research.

Rothwell, William J. 2010. Effective Succession Planning. USA : American Management Association.

Vince, Fernando Kevin., 2008. Aligning Recruitment to Talent Management Efforts. Victoria State Government. 2019. Human Resource Succession Planning. 